\title{
HIGH SCHOOLERS FOR HIGH SCHOOLERS AS SUPPORT TO STUDENTS' SOCIAL-EMOTIONAL AND INTERPERSONAL (SEI) COMPETENCES ENFORCEMENT
}

\author{
Sanja Vučetić \\ XV. gimnazija, Zagreb \\ Ana Dundović
}

\begin{abstract}
It is with great interest that the modern society of today has been discussing the 'society of knowledge' and the 'society of education', putting great emphasis on the professional and educational role of the teacher and environment within the process of a life-long education of students. The project in question was set up to correspond with the idea of the comprehensive curricular reform of the Croatian education system together with the programme 'School for Life', and it aims to encourage and develop social-emotional as well as interpersonal (SEI) competences in students and teachers, taking into consideration that the competences in question have been proven to have a positive effect on students' academic success and skills improvement, as well as on their general development. A secondary goal of the project was to present good practice examples with special attention paid to activities of prevention in a partner-school, with students as mediators. This research was undertaken as a part of the 'High Schoolers for High Schoolers' project, from October 2018 to April 2019, in form of a single visit to both schools, which included interactive workshops previously prepared by schools. The workshops were conducted by students mediators, that is four senior grade students from XV. gimnazija as members of a psychology-group, and five 11th-grade students mediators from Gimnazija Josipa Slavenskog in Čakovec. Forty-five 9th- and 11th-grade students from XV. gimnazija and seventy-five 9th- and 10th-grade students from Gimnazija Josipa Slavenskog participated in the project. A test sample consisted of four students mediators and fortyfive students participants from XV. gimnazija. As for the project evaluation, two short questionnaires were designed, depending on the role of the examinees in the project (student mediator or student participant), with a 5 point Likert scale to be completed at the end of a visit. A descriptive data analysis was conducted using the SPSS 20.0 system, and the process and content evaluation results show a stronger collaboration effect, as well as a stronger satisfaction level in terms of collaboration, in case of students mediators than in case of other students participants, in almost all estimated items. The results support further collaboration of this kind.
\end{abstract}

Keywords: evaluation, inter-school collaboration, SEl competences, School for Life, activities of prevention in school.

\section{INTRODUCTION}

Accelerated technological development and civilizational changes we are witnessing, significantly affect the reflections about the setting of educational goals. Considerations of the goals of the educational system to modernize it in a form of a shift from the content-oriented curricula to educational learning outcomes, are described in the literature of various contemporary theorists and researchers (Bognar, 2007). Consequently, new tasks aimed at lifelong learning of students, require new competencies of teachers in their professionalism (Hercigo- 
nja, 2018); therefore special emphasis is put on the methods of encouraging and developing social-emotional and interpersonal (SEI) competencies in order to move from one-way content transfer to construction of knowledge and skills and their application in practice (Payton et al., 2008; UNESCO, 2015). According to the Institute for Social Research in Zagreb (2017), with Croatia's accession to the European Union the importance of implementing methods of encouraging SEI competencies has become even more relevant due to the new opportunities for professional development of school staff, international cooperation in student exchange projects and programmes, networking with international technology platforms and programmes for teaching and informing parents about students' achievements.

Guided by the above premise, the plan for improving Croatian educational system was already elaborated and articulated in the National Frame Curriculum for Preschool Education and General Compulsory and Secondary Education (2011) and the Education, Science and Technology Strategy (2014). Both documents emphasize the development of competences for lifelong learning, i.e. generic competences, as one of the main goals of the educational system. This phrase implies a clear definition of educational outcomes that are not only cognitive in nature but also include the development of critical thinking competencies, innovation, creativity, entrepreneurship, self-esteem, relationships with others and the environment, and many others. Furthermore, goals in relation to the student should be set so to provide him with the education that will enable them to live and work in the modern world. Goals in relation to the teacher should enable the teacher creativity and autonomy in work, and to students' parents a greater opportunity to participate in creating and monitoring the achievement of educational outcomes (Hercigonja, 2018).

In accordance with the stated objectives, great importance is given to planning, implementation and monitoring of the outcomes of cross-curricular topics in a proposal of the Comprehensive Curriculum Reform (2016). In the experimental part of the reform implementation called "School for Life", the following topics stand out: learning how to learn, entrepreneurship, personal and social development, health, information and communication technology usage, civic education and sustainable development.

\section{Sel COMPETENCIES}

The development of SEI competencies is based on the CASEL model (2013) stating five dimensions that can also apply to school staff (Schonert-Reichl, Hanson-Peterson and Hymel, 2015). These dimensions include:

- self-awareness (identifying and recognizing emotions and understanding the impact on behaviour, accurate self-perception, recognizing one's own strengths, needs and values, self-efficacy);

- self-management (impulse control and regulation of one's own emotions, thoughts, behaviours, self-motivation and discipline, stress management);

- social awareness (appreciating diversity, perspective taking, empathy, respect for others, understanding and respect for family, school, community resources);

- interpersonal skills (maintaining positive and rewarding relationships, communication competencies, social engagement and relationship building, work collaboration, conflict management), and

- responsible decision-making (problem solving, making constructive and respectful choices about personal behaviour and social interactions based on personal, moral and ethical responsibility). 
Intercultural (I) competencies imply the ability to communicate effectively and appropriately in an intercultural context (Deardorff, 2004; Schonert-Reichl, Hanson-Peterson et al., 2015), and consist of:

- intercultural knowledge (self-awareness, understanding and knowledge of cultural differences);

- competencies (e.g. the ability to see a situation from the perspective of another listening, observing and interpreting; analysing, evaluating and perceiving relationships; the ability to interpret a document or event from the perspective of different cultures; the ability to acquire new knowledge about culture and its customs), and

- attitudes (respect for and appreciation of other cultures, cultural diversity; openness to intercultural learning and people from other cultures; refraining from making judgments; curiosity and propensity to discover and tolerating ambiguity and insecurity).

According to the research by Payton et al. (2008) there is a positive correlation between better educational outcomes and the SEI competencies development. In fact, the research has shown that better educational results are a direct consequence of the SEI competencies development in students. The positive effects of SEI competencies on success at school have also been demonstrated in the recent CASEL research (2017) and OECD reports (2018), which concluded that students with better developed SEI competencies, in addition to better educational success, also take better care of their mental health, pro-social behaviour, show less physical aggression, have more positive self-perception, and drop out of school less often. They are also more active in the classroom, expressing opinions and views more clearly, including, evaluating and accepting the opinions of others, and maintaining better relationships with peers and school staff.

However, according to Razdevšek - Pučko (2005: 102) "the vision of lifelong learning and continuous professional development requires a teacher who will be able to think critically, who is capable of reflection and evaluation, who knows how to seek or provide prerequisites for the development of each student, and who knows to encourage and support students in their learning process". The European Commission document (2005) lists three general teacher competence categories (working with others, working in and with society, and working with information, technology and knowledge), but according to Hercigonja (2018) in order that the teachers can encourage the SEI competences development in students six more new competency areas need to be added. These include:

- teaching with the use of modern information and communication technology (ICT) and information literacy,

- competence for new ways of work in and outside the classroom, at school and with social partners,

- developing students' lifelong learning competencies in a knowledge society („teaching them how to learn "),

- developing their own professionalism,

- ability to notice the connection between certain aspects of educational theories, educational policy and educational practice, and work in a group with different children, even multiculturally mixed groups with successful conflict resolution, and

- ability to recognize and respond to students' individual needs as well as to the learning process complexity and to include the children with special needs.

The seven-year survey of 400 primary schools conducted by Anthony Bryk and Barbara Schneider in 2004 supports the fact that it is necessary to have well-developed SEI teacher competencies in order to encourage these in students. It has been shown that the quality of social relations within the school community, consisting of the principal, school staff and 
students, is the key to students' success, and it strongly predicts positive outcomes for students. Finally, intercultural competencies development contributes to a more tolerant and secure school environment by enabling inclusiveness in education, especially of the vulnerable groups of students (Payton et al., 2008). Thus, the teacher should be the first to follow modern education trends and to direct their professional work within this framework. Professionalism includes continuous vocational development, devising new methods of interdisciplinary content integration, and showing interest in and situational awareness of other subject areas. Therefore, as already mentioned, teachers' professionalization extends to collaborative work and the evaluation of their own work, as well as to their practice improvement (Hercigonja, 2018). Inter-school cooperation is a relatively new area of research in education, and due to its different forms, it is difficult to define and classify it. According to the available literature, effective collaboration should include shared resources, shared activities, benefits, but also potential risks for the participants involved (Atkinson et al., 2007).

Foreign experience also shows that SEI competencies in teachers, professional associates and students can be effectively developed through cooperation and partnership of schools. One illustrative example is the inter-school collaboration project in Northern Ireland, in which social-economic and political circumstances in Northern Ireland caused this need in order to reconcile two groups with traditionally disrupted relations: the Catholics and the Protestants (Gallagher et al., 2010). An additional reason to encourage such cooperation was to ensure equal access to all teaching and extracurricular education programs for all students. The cooperation between the schools had thus become a priority in the national curriculum and documents, and the benefits of cooperation were highlighted at the state level (DENI, 2006). The evaluation of the project showed that two out of five students, before engaging in joint educational activities, had never met a person of another religion. Research indicated that mutual cooperation encourages the growth of self-confidence, a sense of comfort in contact with students from different backgrounds and the acquisition of new competencies and experiences in students. It has been shown that, using this type of cooperation, teachers built positive relationships among schools, acquired and provided new knowledge and competencies, and influenced the increase of awareness of other cultures among students. However, it should be pointed out that teachers were also dissatisfied, and they warned against lack of time for effective planning and joint activities implementation, schedules harmonization and organization of students' transportation.

The conclusions of the Irish study provided also incentives for research of teachers' SEI competencies and their development within the overall curriculum reform in Croatia (Blažević, 2014; Brust Nemet, 2015; Topić, 2016). The results of the most extensive survey in Croatia, conducted among 696 teachers in 30 primary schools in Slavonian counties, show that demographic characteristics are not as important for predicting the quality of school culture as the social-pedagogical competencies of teachers. In an atmosphere of a more positive school culture, teachers can, "with their competence and lifelong education, meet the requirements of a modern student, who is changing intensively on a daily basis under the influence of global factors" (Brus Nemet, Velki, 2016:1119). A study in Croatia has shown that the changes "are possible only with strong will, commitment and support of all participants in education who can contribute to a better educational system in the Republic of Croatia, which presupposes changing of study and lifelong learning programmes, and discovering hidden elements of each school in order to raise awareness and improve school culture" (Brust Nemet, 2015). 


\section{Peer-to-Peer (P2P) INTERActions}

In addition to generic competencies and outcomes, Comprehensive Curriculum Reform (2016) also emphasizes the innovative work methods derived from teacher's autonomy, aimed at increasing student's motivation to learn and student's active participation in the learning and teaching process. Considering that the most effective learning is the one in which we teach others (Bašić, 2017), it does not surprise the authors' interest in studying peers' interventions ("peer-to-peer intervention"). Peer-led intervention based on the principles of behaviourism and social learning theory has proven to be a good example of practice in the United States. The intervention was designed to increase the quality and quantity of the social inclusion of children with disabilities under natural conditions (Bašić, 2017). Furthermore, a proven useful example of good practice is the American Peers Making Peace (PMP) program. The goal of the PMP program is to reduce the rate of violence and improve the academic achievements of students from preschool to the final grade of high school. It is based on the acquisition of life and social competencies, conflict prevention and resolution competencies, training of parents for conflict resolution, peer mentoring and model learning (Youth.gov, 2019).

Research in Croatia describing peer interventions is relatively scarce, and refer to kindergarten age (Begić, 2016) or peer support as a form of intervention in children with disabilities (Bašić, 2017). The preventive health education program MEMOAIDS or Youth Educating Youth on AIDS had a slightly larger impact among the high school population. The introduction of MEMOAIDS into Croatian secondary schools in 2004 was a consequence of an agreement signed between the Government of the Republic of Croatia and the Global Fund to Fight AIDS, Tuberculosis and Malaria (Ćuk, 2004).

An example of good practice of peer mediation in Croatia is the "Peer Mediation Academy" implemented by the Forum for Freedom in Education with the support of the City of Zagreb since 2015. The aim of this project is to train high school students and future professionals working with children to conduct workshops in communication, conflict resolution, mediation and human rights. "Academy" is now a part of the project "Small mediators in a happy school of social-emotional competence of children and youth for constructive conflict resolution and acceptance of diversity" which aims to train students in selected schools in Zagreb, Međimurje and Brodsko-posavska county at "more successful communication and nonviolent conflict resolution, and strengthening of personal and social competencies" (Forum for Freedom in Education, 2015).

Recognizing the importance and potential of peer interventions, XV. gimnazija in Zagreb has systematically implemented peer intervention programme since 2015 . The interventions are planned so that the students, the Psychological Group members (11th grade), conduct workshops on learning in the first semester of the current school year, and SMART workshops (workshops about smart goal setting) with the 9th-grade students in the second semester. The workshops "Your 40\%" empower the 9th-high school students to take responsibility for solving problems primarily for their own learning, and thus make it easier for them to adapt to the science-mathematics high school programme. "The workshops have multiple advantages: the adaptation to the new environment is easier for beginner students, the development of social and communication skills is more significant for student mediators, and the contribution to a more pleasant and quality school environment is greater for the whole school" (Pavlin-Bernardić and Vučetić, 2018). Furthermore, the same institution has been conducting learning workshops with student mediators since 2016, and it has also been conducting SMART workshops for 8th-grade students in the neighbouring primary schools since 2017. In this way XV. gimnazija in Zagreb contributes to the development of lifelong learning, inter-school cooperation, creates stimulating environment and promotes its own school values. 
THEORETICAL AND PRACTICAL PROBLEMS AND DISCUSSIONS

TEORIJSKI I PRAKTIČNI PROBLEMII RASPRAVE

\section{Project description AND EVALUATION}

The project "High Schoolers for High Schoolers" was jointly created in May 2018 by the school psychologist from Gimnazija Josip Slavenski in Čakovec and the school psychologist and psychology teacher from XV. gimnazija in Zagreb, encouraged by the proposal of the entire curriculum reform of the Croatian educational system and the project "School for Life" with the aim of encouraging and developing SEI competencies. The secondary goal of the project was to present examples of good practice with an emphasis on preventive activities in the partner school conducted by student mediators.

In addition to encouraging the SEI competencies development the project aims included:

1. Encouraging and adopting motivational strategies of self-regulated learning; acquiring new skills through peer learning,

2. Encouraging and developing responsible life decisions and teamwork skills in students,

3. Increasing pleasant emotions during educational process, and the development of empathy,

4. Providing insight into the work of the partner school, exchange of experiences and making new acquaintances, and mutual support.

The planned collaboration is supported at the education system level (approval of the institutions' principals of and students' parents), and thus one of the necessary preconditions for its effectiveness was achieved. School psychologists and school pedagogues of both schools participated in the research implementation within the project "High Schoolers for High Schoolers".

The sample of examinees for this research consists of four students mediators, members of the Psychological Group and forty-five students participants from XV. gimnazija in Zagreb, and five 11th-grade students mediators and seventy-five 9th- and 10th-grade students from Gimnazija Josip Slavenski in Čakovec also participated in the project.

The research was conducted from September to April 2019 as a part of two mutual visits of schools in which each school prepared the interactive workshops and presented techniques and methods that will enable better SEI competencies development of their students (saving time, selecting important information, memory, assertive communication, positive self-image development, self-confidence, healthy lifestyle, balanced diet, youthful relationships, responsible Internet usage and quality leisure time). The realization of the visit was preceded by the preparation of the programme of activities carried out by student mediators in the partner schools.

On Monday, November 26, 2018, the students, the school psychologist and the pedagogue from the XV. gimnazija visited the 9th- and 10th-grade students of Gimnazija Josip Slavenski in Čakovec. The aim of the visit was to present techniques and methods that will enable students to better organize their time and learn more successfully ("teach them how to learn"). The interactive workshop method lasting for one school hour was chosen as the way to achieve the goal.

On Wednesday, April 10, 2019, a return visit was made by five 11 th-grade students, the school psychologist and the pedagogue from Gimnazija Josip Slavenski in Čakovec to XV. gimnazija in Zagreb. An interactive workshop, lasting for 45 minutes, called "I play and learn" was conducted with the aim of developing areas of SEI competencies (social, emotional and intercultural): assertive communication, positive self-image development, self-confidence, healthy lifestyles, balanced diet, youthful relationships, responsible Internet usage and quality leisure time). 
As for the project evaluation, two short questionnaires were designed, depending on the role of the examinees in the project (student mediator or student participant), with a 5 point Likert scale to be completed at the end of a visit. The questionnaire intended for student mediators included satisfaction variables resulting from the possibility of meeting and socializing with peers from other schools, and self-assessment of the competencies acquisition: learning in a new and different way, communication, presentation skills, coping in new situations, easier decision making, more successful collaboration and easier understanding of one's own and needs of others. The questionnaire intended for students participants differed from the one for mediators in one variable, so instead of examining the self-assessment of the presentation skills development, it examined the participants mood during the workshop.

The research limitations referred to the unequal number of the examinees, student mediators and student participants, metric characteristics of the evaluation questionnaire and heterogeneity of the test sample were not checked, as well as the statistical data processing of only one school (XV. gimnazija in Zagreb) was performed, therefore the results were based on descriptive analysis. The graphs show the descriptive statistics results, and Table 1 shows the results of analysis of variance (ANOVA) which examined the statistical significance of the difference in the evaluation results between younger and older students participants (results of 9th- and 11th grade).

\section{RESULTS AND DISCUSSION}

The data obtained from the evaluation questionnaires were statistically processed using the SPSS 20.0 program, and the methods used in the data collection and processing include: inductive and deductive method, analysis and synthesis, generalizations and specialization, classification, description, compilation and comparison. The data collected were sampled in one school only, XV. gimnazija in Zagreb (Graph 1).

Because the sample of student mediators $(n=4)$ is significantly smaller than the sample of student participants $(n=45)$, the difference between them was not examined. The total number of students included in the evaluation is 49 .

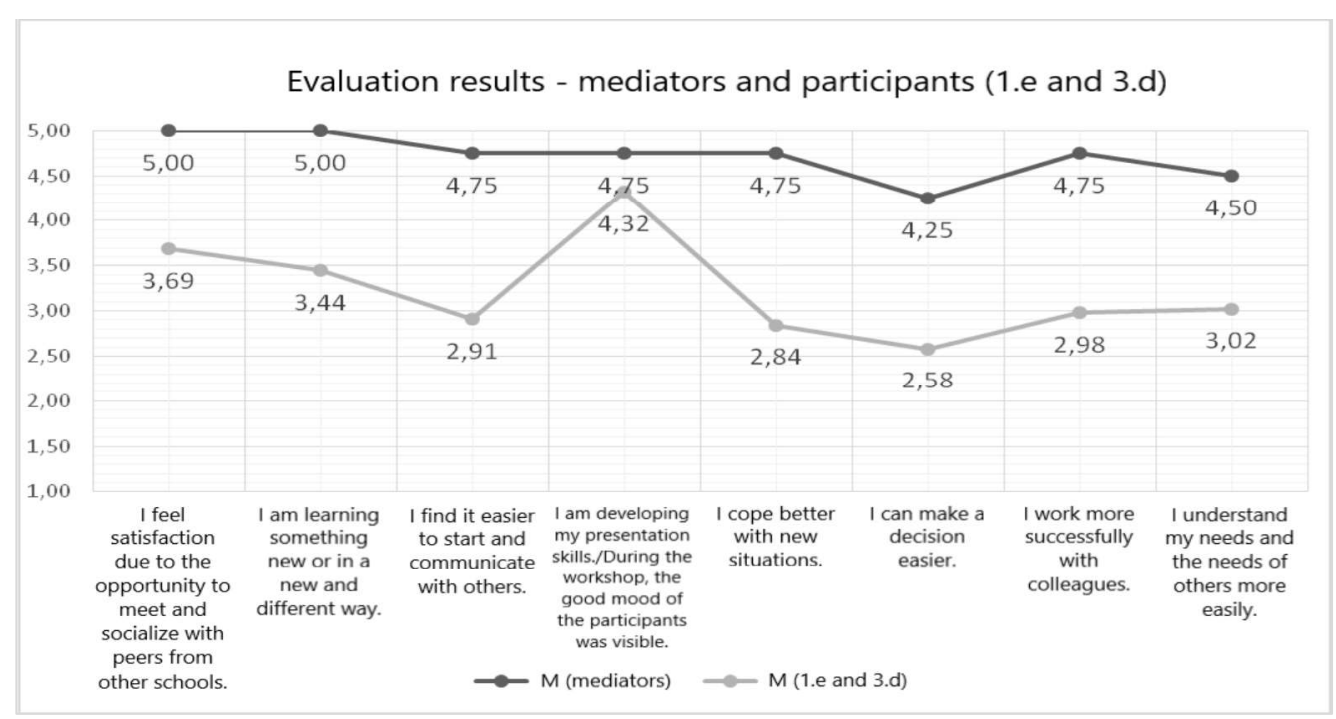

Graph 1: Results (M) of student mediators $(N=4)$ and student participants (45) obtained by the evaluation questionnaire 
THEORETICAL AND PRACTICAL PROBLEMS AND DISCUSSIONS

TEORIJSKI I PRAKTIČNI PROBLEMI I RASPRAVE

Graph 1 shows a stronger satisfaction level in terms of collaboration, in case of students mediators than in case of other students participants, in almost all estimated items

It was estimated that the greatest benefit in case of student mediators is their active participation in the project on the learning variable (learning in a new and different way) and satisfaction with the opportunity to socialize with peers from other schools. The variables of facilitated communication, presentation skills development, coping in new situations and cooperation with colleagues were slightly lower, and the weakest effects were recorded on the variable of decision-making skills. However, the recorded results are still high (4.25>).

In contrast to the student mediators, the survey results for student participants cover a range of mean values from 4.32 to 2.58 , and indicate moderate to very good satisfaction with the effects of collaboration on the assessed variables. The highest result was achieved on the good mood variable (4.32). A high result was also achieved on the satisfaction variable due to the possibility of meeting and socializing with peers from other schools (3.69) and the possibility of learning in a new and different way (3.44). The variables related to communication, coping in new situations, collaboration with colleagues and understanding one's own and needs of others did not achieve the hypothesized significant result. The weakest result was recorded on the variable of decision-making skills (2.58).

The same procedure was repeated for the students participants, and the differences in results with regards to their age are shown in Graph 2.

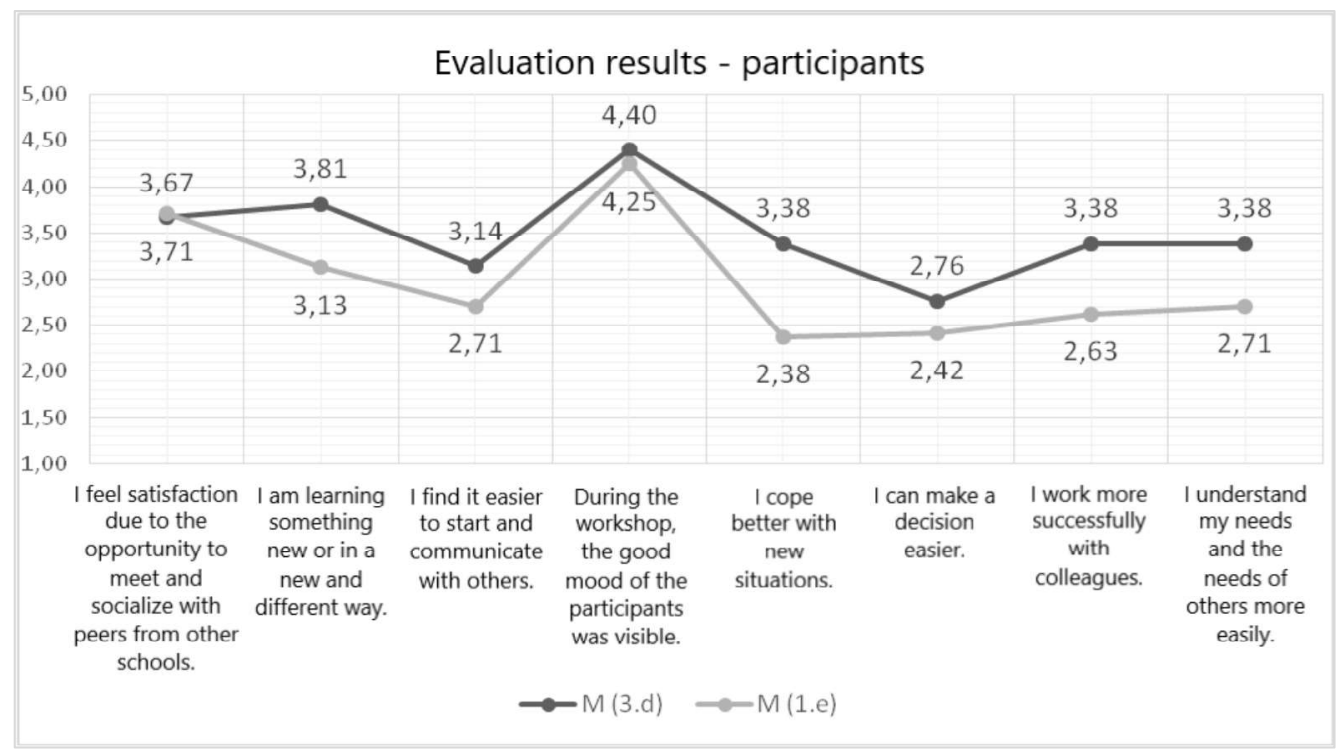

Graph 2: Results of student participants (M) from 9th- and 11th-grade (N=45) obtained by the evaluation questionnaire

The analysis of Graph 2 shows that the self-assessment of changes in social-emotional competencies stimulated by the inter-school student interaction is lower in case of younger students than in case of older students and it refers to almost all variables.

Checking the statistical significance of these observed differences with respect to the students' age was performed by ANOVA test and is shown in Table 1. The results of analysis of variance show that the student inter-school interaction had a stronger effect on the older 
students, in the area of better coping in new situations ( $F=6.9 ; p<0.01)$, and borderline in learning in a new and different way $(\mathrm{F}=3.5 ; \mathrm{p}<0.07)$ and in more successful cooperation with the colleagues $(F=3.33 ; p<0.075)$.

Table No. 1. ANOVA for the results of the students participants from 9th- and 11th-grade

\begin{tabular}{|c|c|c|c|c|}
\hline ITEM & $\begin{array}{c}M \\
(1 . e)\end{array}$ & $\stackrel{M}{(3 . d)}$ & $\mathrm{F}$ & $\mathrm{p}$ \\
\hline $\begin{array}{l}\text { 1. I feel satisfaction due to the opportunity to meet and } \\
\text { socialize with peers from other schools. }\end{array}$ & 3,71 & 3,67 & 0,013 & 0,911 \\
\hline 2. I am learning something new or in a new and different way. & 3,13 & 3,81 & 3,534 & 0,067 \\
\hline 3. I find it easier to start and communicate with others. & 2,71 & 3,14 & 1,115 & 0,297 \\
\hline $\begin{array}{l}\text { 4. The good mood of the participants was visible during the } \\
\text { workshop, }\end{array}$ & 4,25 & 4,40 & 0,262 & 0,611 \\
\hline 5. I cope better in new situations. & 2,38 & 3,38 & 6,905 & 0,012 \\
\hline 6. I can make a decision easier. & 2,42 & 2,76 & 0,686 & 0,412 \\
\hline 7. I collaborate with my colleagues more successfully. & 2,63 & 3,38 & 3,333 & 0,075 \\
\hline 8. I can easier understand my needs and the needs of others. & 2,71 & 3,38 & 2,948 & 0,093 \\
\hline
\end{tabular}

The results of the descriptive analysis of the notes the students participants in the project were free to write in the blank space of the questionnaire, further support the obtained results. The most common and characteristic notes to describe the student experience are listed below:

- "Nice experience!

- Great.

- It was awesome!

- It was fun even though I didn't learn much new staff.

- It was enjoyable, fun and educational.

- It was interesting.

- It was great for me, it was just too easy.

- The game was interesting and we had a lot of fun.

- I had a good time with the company of classmates, an experience that needs to be repeated.

- It is good to have something like that, for a change."

The results of the descriptive analysis of the student mediators' comments prove the need and effectiveness of continuing this type of collaboration: "I think there should be more such exchanges because they allow people from different backgrounds to meet each other, and this motivated me to think about whether I appreciate some values in life enough. After this exchange, I started to look at some things differently and to better understand people from similar backgrounds."

\section{Conclusion}

The descriptive analysis of the obtained data and ANOVA test showed a positive impact of the inter-school peer interactions on the development of SEl competencies in case of students participants, which confirmed the previous research. 
THEORETICAL AND PRACTICAL PROBLEMS AND DISCUSSIONS

TEORIJSKI I PRAKTIČNI PROBLEMI I RASPRAVE

It was found out that the well-planned and implemented inter-school collaboration significantly contributes to the development of social and emotional competencies in case of student mediators, and makes the educational process more pleasant and interesting for all students participants.

The need to continue mutual cooperation was emphasized in order to prevent undesirable forms of behaviour and ineffective learning methods, and the development of knowledge and competencies needed for individual lifelong learning.

In conclusion, the need for the development of the appropriate evaluation instruments and further research on this topic was emphasized.

\section{REFERENCES}

Atkinson, M., Springate, I., Johnson, F. \& Halsey, K. (2007). Inter-school collaboration: a literature review. Retrieved 09/07/2020 from https://www.researchgate.net/publication /237507593_ Interschool_collaboration_a_literature_review

Bašić, K. (2017). Vršnjačka potpora kao oblike intervencije kod djece s teškoćama u razvoju. Zagreb: Edukacijsko-rehabilitacijski fakultet.

Begić, M. (2016). Evaluacija vršnjački vođene intervencije u redovnom vrtiću. Zagreb: Edukacijskorehabilitacijski fakultet.

Blažević, I. (2014.). Suvremeni kurikul i kompetencijski profil učitelja. Split: Filozofski fakultet u Splitu.

Bognar, L. (2007). Hrvatski nacionalni kurikulum (elaborat). Retrieved 24/07/2020 from https://ladislav-bognar.net/node/35

Brust Nemet, M. (2015). Socijalno-pedagoške kompetencije učitelja u kurikulumu kulture suvremene škole (Doktorska disertacija), Zagreb: Filozofski fakultet.

Brust Nemet, M. \& Velki, T. (2016). Socijalne, emocionalne i pedagoške kompetencije nastavnika kao prediktori različitih aspekata kulture škole. Croatian Journal of Education, 18(4), 1087-1119.

CASEL (2017). New meta-analysis shows positive long-term impacts of social and emotional learning, Retrieved 24/07/2020 from https://casel.org/new-meta-analysis-shows-positive-long-termimpacts-of-social-and-emotional-learning/

Cjelovita kurikularna reforma (2016). Službene stranice prijedloga Cjelovite kurikularne reforme. Retrieved 21/07/2020 from http://www.kurikulum.hr/

Ćuk, M. (2004). MEMOAIDS-edukacija o spolnosti na hrvatski način. Obnovljeni život, 59(2), 199-202.

Deardorff, D. K. (2006). Identification and Assessment of Intercultural Competence as a Student Outcome of Internationalization. Journal of Studies in International Education, 10(3), 241-266.

DENI (2006). Schools for the future : funding, strategy, sharing : report of the Independent Strategic Review of Education. Retrieved 24/07/2020 from https://dera.ioe.ac.uk//9777/

Europska komisija za edukaciju i kulturu (2005.). Common European Principles for Teacher Competences and Qualifications. Retrieved 21/07/2020 from http://domus.srce.hr/iuoun/images/ dokumenti/dokumenti170209/principles_en.pdf

Forum za slobodu odgoja (2015). Službene stranice. Retrieved 24/07/2020 from https://fso.hr/

Hercigonja, Z. (2018). Kompetencije nastavnika i učenika u postizanju optimalnoga obrazovanja. Zbornik radova Međimurskog veleučilišta u Čakovcu, 9(1), 22-30.

Institut za društvena istraživanja u Zagrebu. Glasnik Instituta 6/2017. Retrieved 24/07/2020 from https://www.idi.hr/wp-content/uploads/2018/02/glasnik_6_2017.pdf

Nacionalni okvirni kurikulum za predškolski odgoj i obrazovanje te opće obvezno i srednjoškolsko obrazovanje (2011). Zagreb : Ministarstvo znanosti, obrazovanja i športa.

OECD (2018). Social and emotional skills: Well-being, connectedness and success. Retrieved 10/06/2020 from http://www.oecd.org/education/school/UPDATED\%20Social\%20and\%20 Emotional\%20Skills\%20-\%20Well-being,\%20connectedness\%20and\%20success.pdf\%20 (website).pdf 
Payton, J., Resnik, H.,Weissberg, R, Durlak, J., Dymnicki, A.,Taylor, R., Schellinger, K. \& Pachan, M. (2008). The Positive Impact of Social and Emotional Learning for Kindergarten to Eighth-Grade Students: Findings from Three Scientific Reviews. Chicago: Collaborative for Academic, Social, and Emotional Learning

Pavlin-Bernardić, N. \& Vučetić, S.(2018). Adolescencija, adaptacija, atribucija....lli radionice o učenju. In A. Brajša-Žganec, Z. Penezić \& M. Tadić Vujčić (Eds.), 26. Godišnja konferencija hrvatskih psihologa: Sažeci priopćenja (pp. 205-205). Jastrebarsko: Naklada Slap.

Razdevšek-Pučko, C.(2005). Kakvog učitelja/nastavnika treba (očekuje) škola danas (i sutra)? Retrieved 10/07/2020 from http://www.see-educoop.net/education_in/pdf/kompetence-uciteljevslo-hrv-t07.pdf

Schonert-Reichl, K. A., Hanson-Peterson, J. L., \& Hymel, S. (2015). SEL and preservice teacher education. In J. A. Durlak, C. E. Domitrovitch, R. P. Weissberg, i T. P. Gullotta (Eds.), Handbook of social emotional learning: Research and practice (pp. $406-422$ ). New York: The Guilford Press.

Strategija obrazovanja, znanosti i tehnologije (2014). Narodne novine br.124/2014.

Topić, A. (2016). Pedagoške kompetencije učitelja primarnog obrazovanja (Diplomski rad). Osijek: Fakultet za odgojne i obrazovne znanosti.

UNESCO (2015). Rethinking education: towards a global common good?. Retrieved 10/07/2020 from https://unesdoc.unesco.org/ark:/48223/pf0000232555

Youth.gov (2018). Peers making peace. Retrieved 10/07/2020 from https://youth.gov/content/peers-making-peace 